Castañeda-Ruelas Gloria Marisol ${ }^{1}$

(1) 0000-0001-8970-0035

Fajardo López Ana Josefina ${ }^{2}$

(i) 0000-0002-9564-8023

Berrios José De J. ${ }^{3}$

(i) 0000-0001-5557-6267

Mendoza-López Ilianne Annel

(D) 0000-0002-1239-5156

'Universidad Autónoma de Sinaloa, Facultad de Ciencias Químico Biológicas

${ }^{2}$ Tecnológico Nacional de México, Campus Culiacán

${ }^{3}$ United States Department of Agriculture (USDA),

Agricultural Research Service (ARS),

Western Regional Research Center (WRRC)

*Corresponding authors: Email address:

ilianne.ml@culiacan.tecnm.mx

\section{Growth yield and health benefit of farm shrimp (Litopenaeus vannamei) fed in a pre-fattening phase with a diet based on wheat (Triticum sativum) and chickpea (Cicer arietinum) enriched with spirulina (Spirulina maxima)}

\begin{abstract}
The formulation of diets from vegetable protein enriched with immunostimulants is a suitable feeding strategy for shrimp culture. This study evaluated a feed formulated with wheat (Tritium sativum) and chickpea (Cicer arietinum) enriched with spirulina (Spirulina maxima) for shrimp Litopenaeus vannamei farming. A feed based on wheat and chickpea (2.5:1) containing $3 \%$ spirulina was developed and characterized by proximal chemical analysis. The experimental feed was evaluated along with a commercial feed in a five-week field bioassay to determine the growth, survival, and health status of the juvenile shrimp. In addition, water salinity $\left(\mathrm{mg} \cdot \mathrm{L}^{-1}\right)$ was monitored as an environmental stability factor for shrimp cultures. The proximal chemical composition of the experimental feed contained $17.5 \pm 0.1 \%$ protein, $2.2 \pm 0.3 \%$ lipids and $68.0 \pm 0.3 \%$ carbohydrates. The specific growth rate $\left(0.22 \pm 0.05 \mathrm{~g}\right.$ days $\left.^{-1}\right)$ of the shrimp under experimental feed did not show statistical differences in comparison with the commercial feed $(P>0.05)$. Also, it was determined that the shrimp fed with experimental feed presented a biomass production $(0.74 \pm 0.17 \mathrm{~g})$, survival rate $(>98 \%)(P<0.05)$ and health status better than shrimp fed with commercial feed. The influence of salinity on shrimp survival was rule out $(P>0.05)$. This study demonstrated that the experimental feed offers a suitable diet in benefit of the performance and health of the shrimp.
\end{abstract}

Keywords: diet, Litopenaeus vannamei, spirulina, vegetable protein, weight gain.

\section{Cite this as:}

Castañeda-Ruelas GM, Fajardo López AJ, Berrios I de J, Mendoza-López IA. Growth yield and health benefit of farm shrimp (Litopenaeus vannameI) fed in a pre-fattening phase with a diet based on wheat (Triticum sativum) and chickpea (Cicer arietinum) enriched with spirulina (Spirulina maxima). Veterinaria México OA. 2022;9. Doi: 10.22201/ fmvz.24486760e.2022.966 


\section{Introduction}

In Mexico, the shrimp farming industry is an important source of food and wealth for the country; Litopenaeus vannamei (white shrimp) is the main domesticated shrimp specie (Cortés et al., 2021). Shrimp farming is an economic activity developed worldwide, whose production has decreased due to the impact of infectious diseases (Cock et al., 2009), a situation from which Mexico is not exempt (Gómez-Gil et al., 2011). Sinaloa is recognized as a state with a distinguished shrimp farming due to soil quality, water, climate, and larval availability. In 2018, Sinaloa achieved a production of 105 thousand tons of shrimp, which represented a contribution of $46 \%$ of the value generated nationwide (CONAPESCA, 2018).

Shrimp farming has different aspects that must be considered; the shrimp species (Cortés et al., 2021), the feeding strategy (Suárez et al., 2009; Cortés et al., 2021), the environmental conditions of the farms (Valenzuela-Quiñonez et al., 2010), the number of shrimps per $m^{2}$ during feeding (Simão et al., 2013), as well as the effect of physicochemical parameters such as the availability of dissolved oxygen, salinity, and temperature in the ponds (Vinatea et al., 2011). It has been documented that feeding is the key factor in shrimp culture because it defines the degree of development of the crustacean and the time that is invested in the farming cultivation (Raham et al., 2017). Shrimp feeding depends on the nutrients and ingredients incorporated in the diet (Joblingh, 2012).

Protein content is related to shrimp weight gain, and it can be provided through various sources of plant and animal origin. Feed based on animal proteins are the most used, with fish meal usually constituting commercial feed due to their high protein content and polyunsaturated fatty acids (Stevanato et al., 2008; Espinoza-Chaurand et al., 2015). However, fishmeal is considered one of the most expensive ingredients. Some studies have proposed the partial or complete replacement of animal protein due to ecological and economic factors involved in the use of fishmeal (Amaya et al., 2007).

Vegetable flours (wheat, chickpea, rice, canola, soybeans, among others) can be the total source of protein in the farm shrimp diet, since these flours are natural binders that contribute to the hydrostability of the feed, allowing the reduction or exclusion of synthetic binders (Cock et al., 2009; Cortés et al., 2021). Wheat and chickpea are regional crops that could represent an attractive alternative in the partial or total replacement of animal protein in diets and animal feed, due to their nutritional content, amino acid profile, adequate energy intake for nutrition and fattening of animals, and low cost (Reyes-Moreno et al., 2000; Žilić et al., 2011).

Another relevant aspect of the composition of feed for shrimp and other crustaceans is the inclusion of ingredients that strengthen the immune system and present an attractive appearance for animals (Wang et al., 2016; Jaime-Ceballos et al., 2017). The use of unicellular algae of the Cyanobacteria family such as Spirulina, Chlorella, and Dunalliella have been identified as safe functional ingredients or foods, due to their high-quality protein composition, $\boldsymbol{\gamma}$-linoleic acid, vitamins, minerals, carotenoids, and sulfated polysaccharides (Tang and Suter, 2011 ; Gutiérrez-Salmeán et al., 2015). It should be noted that the inclusion of Spirulina maxima algae in the diet for shrimp farming is beginning to be explored for its nutritional and nutraceutical benefits (Macias-Sancho et al., 2014; Chen et al., 2016).

Hence, it is important to offer a balanced and enriched diet of vegetable origin for shrimp farming that allows obtaining an efficient harvest in terms of growth, sur- 
vival, with reduced production costs and in harmony with ecological factors. The objective of the study was to generate an efficient feeding strategy for the production of a white shrimp farm (Litopenaeus vannamei) in the pre-fattening stage using a feed made from wheat flour (Triticum sativum) and chickpea (Cicer arietinum) and enriched with spirulina (Spirulina maximum).

\section{Materials and methods Ingredients and feed preparation}

To describe the contribution of spirulina (Spirulina maxima) in the vegetable protein diet, a feed based on wheat (Triticum sativum) and chickpea (Cicer arietinum) was prepared, containing 0\% and 3\% of spirulina. The wheat, chickpea and spirulina were obtained from local markets in Sinaloa, México. For the preparation of the feed, the powdered wheat and chickpea ingredients were mixed at a ratio of 2.5:1, adding the corresponding percentage of spirulina supplement (0\% and $3 \% \mathrm{w} / \mathrm{w})$, and mixed for $10 \mathrm{~min}$, until their complete homogenization. The mixtures were adjusted to a moisture content of $12 \%(\mathrm{w} / \mathrm{v})$ and were pelletized in a pelletizing machine (Model KL120B/C, China) with a production capacity of 70 to $100 \mathrm{kgh}^{-1}$. The vegetable mixtures were passed through a circular die with a diameter of $2.5^{\prime} 3 \mathrm{~mm}$, at a temperature of $60-80^{\circ} \mathrm{C}$. The resulting pellets were dried in a stove (Felisa FE-132, México) under constant air flow at $85^{\circ} \mathrm{C}$ for 15 minutes. Then, the dried pellets were stored at room temperature $\left(25^{\circ} \mathrm{C}\right)$. The formulation of the experimental feed is not included because it is in the process of patent registration (MX/E/2018/090734).

\section{Proximal chemical analysis}

The chemical analysis of the experimental feeds ( $0 \%$ and $3 \%$ of spirulina) were carried out using standard procedures of AOAC (AOAC, 1990), for the determination of humidity by oven drying method (AOAC 930.15), ashes by calcination method (AOAC 942.05), protein by Kjeldahl method (AOAC 984.13), fats by the Soxhtlet method (AOAC 920.39), raw fiber by digestion method (AOAC 962.09) and carbohydrates by weight difference. The values were expressed as a percentage (\%). Proximal chemical characterization was performed in triplicate for each feed.

\section{Hydrostability}

The percentage of hydrostability (\%) of the experimental feeds was determined following the methodology described by Obaldo et al., (2002). A sample of $25 \mathrm{~g}$ of each feed was homogenized in $100 \mathrm{~mL}$ of distilled water with continuous stirring at $200 \mathrm{rpm}$ for $30 \mathrm{~min}$. Subsequently, the mixture was filtered $(850 \mu \mathrm{m})$, and the solid phase was dried at $130^{\circ} \mathrm{C}$ for $2 \mathrm{~h}$. The percentage ( $\% \mathrm{w} / \mathrm{w}$ ) of hydrostability was determined from the weight of the resulting solid phase. The analysis was performed in triplicate. 


\section{Shrimp farming production}

To carry out this study, four shrimp farms located in the Cospita (Farms A and B) and Elota (Farms C and D) areas of the State of Sinaloa participated consensually. Postlarvae of white shrimp (Litopenaeus vannamei) from the indicated farms were used. Prior to the start of the study, the health of the shrimp and the initial average weight of shrimps (0.17-0.2 g) were determined. In each participating farms $(A-D)$, four stainless steel cages containing 10 postlarvae each per $\mathrm{m}^{2}$ were placed: two cages that were randomly assigned for shrimp under the experimental feed and two cages for those under the control feed. The cages were lined with plastic mesh $\left(1 \mathrm{~m}^{3}\right)$ to isolate each experimental group. During the study, the saline concentration ( $\mathrm{mg} \cdot \mathrm{L}^{-1}$ ) of the water used for shrimp farming was measured as an environmental stability factor using a salinometer (Rhs-28ATC, YHequipment, China).

\section{Growth and survival assessment}

A field test was carried out for 5 weeks to evaluate the benefits of the experimental feed based on wheat and chickpea containing 3\% of spirulina for the white shrimp growth in the pre-fattening phase. A commercial feed (MaltaCleyton ${ }^{\circledR}$, Mexico) made from animal protein and other ingredients was used as a control. For the supply of feed, the initial average weight of ten shrimp per group was determined $(2.56 \pm 1.2 \mathrm{~g})$, which were placed in the cages and raised with the two different types of feed: control (commercial) and experimental (with Spirulina 3\%). Feed was supplied every $12 \mathrm{~h}$, and the daily feeding rate was slowly decreased from $10 \%$ to $8 \%$ of the shrimp biomass during the 35 days of the trial. Each week, all cages were collected to determine the weight and number of surviving shrimps of experimental group $(n=10)$. At the end of the experimental period, the shrimp cultured in the cages of all participating shrimp farms were harvested, counted, and weighed to determine the average weight gain $(\mathrm{g})$, the biomass production $(\mathrm{g})$, specific growth rate per day $\left(\mathrm{g} \cdot \mathrm{day}^{-1}\right)$ and survival rate (\%). These variables were calculated with the following formulas:

$$
\begin{aligned}
& \text { Average weight gain }=\frac{\text { final weight }(g)-\text { initial weight }(g)}{\text { total number of shrimps }} \\
& \text { Biomass production }=\text { average final weight }(g) \times \text { survival rate } \\
& g \cdot \text { day }^{(-1)}=\left[\frac{\text { final weight }(g)-\text { initial weight }(g)}{\text { days }}\right] \\
& \% \text { Survival }=100\left(\frac{\text { final number of shrimps }}{\text { initial number of shrimps }}\right)
\end{aligned}
$$

\section{Health analysis}

For the health analysis, shrimp recovered after the raising period were sent to the State Committee of Aquaculture Health of Sinaloa (CESASIN). The health analysis included fresh bacteriological quantification and pathological study of hepatopancreas, gills, intestine and hemolymph of shrimp by histology. The microbiological 
analysis consisted of the quantification of bacteria (CFU/g) by shrimp organ. For the pathological analysis, the severity of the lesion was reported: negative or low (-), moderate $(+)$ and high (++).

\section{Statistical analysis}

All statistical analysis were performed using the MINITAB 17 statistical analysis program (Minitab Inc., State College, PA, USA). The data generated (final weight, average weight gain, biomass production, specific growth rate and survival rate) from the experimental study was subjected to a randomized complete block design with two treatments (control and experimental feeds) and eight replicates (cages), in total 16 experimental units. The statistical model used was:

$Y_{i j}=\mu+T_{i}+\beta_{j}+\varepsilon_{i j k}$

Where:

$Y_{i j k}$ are the observations of the effect of treatment $i$ in block $j$.

$\mu$ represents overall mean.

$T_{i}$ represents treatment fixed effect (control and experimental feeds).

$\beta_{j}$ represents the block $j$ (eight cages).

$\varepsilon_{i j k}$ represents random error associated with each observation.

When significant $(P \leq 0.05)$ statistics were noted, means were analyzed using a Tukey's test. $A P \leq 0.05$ value was considered statistically significant. Additionally, the general equation of zero order kinetics was used to describe the specific growth rate per day of the shrimp during the feeding time. Pearson's correlation coefficient was also performed for the relationship between the saline concentration $\left(\mathrm{mg} \cdot \mathrm{L}^{-1}\right)$ of the water used for shrimp farming and growth variables (daily weight and survival rate). A $P \leq 0.05$ value was considered statistically significant.

\section{Results and discussion}

\section{Feed characterization}

The feed made from wheat and chickpea enriched with 3\% spirulina, was characterized by a green color, cylindrical shape $(2.5 \mathrm{~mm}$ in diameter) and smooth texture. The proximal chemical analysis of the experimental feeds (0\% and 3\% of spirulina) is shown in Table 1. The experimental feed with spirulina (3\%) favors the protein content $(17.5 \pm 0.1 \%)$ of the mixture of wheat and chickpea flours. Hydrostability in both experimental feeds was $\approx 58 \%$.

Based on practice, it has been assumed that the way shrimp gain weight is directly related to the quality of the protein used in the $\operatorname{diet}^{9}$. Several sources of vegetable protein have been studied and recommended as an alternative for the total or partial replacement of protein of animal origin in food provided for the production of fish and crustaceans, due to the benefit reflected in their weight and size (Suárez et al., 2009; Ayisi et al., 2017; Cortés et al., 2021). Additionally, corn, wheat 
Table 1. Chemical proximal analysis of the experimental feed made from wheat (Triticum sativum) and chickpea (Cicer arietinum) enriched with 0\% y 3\% spirulina (Spirulina maxima).

\begin{tabular}{|l|c|c|c|}
\hline \multicolumn{1}{|c|}{ Parameter } & Unit & $\begin{array}{c}\text { Experimental feed } \\
\mathbf{0} \% \text { spirulina }\end{array}$ & $\begin{array}{c}\text { Experimental feed } \\
\mathbf{3} \% \text { spirulina }\end{array}$ \\
\hline Moisture & $\%$ & $8.0 \pm 0.2$ & $9.6 \pm 0.0$ \\
\hline Proteins & $\%$ & $14.9 \pm 0.1$ & $17.5 \pm 0.1$ \\
\hline Lipids & $\%$ & $3.9 \pm 0.1$ & $2.2 \pm 0.3$ \\
\hline Ash & $\%$ & $2.2 \pm 0.0$ & $2.6 \pm 0.0$ \\
\hline Carbohydrates & $\%$ & $70.7 \pm 0.2$ & $68.0 \pm 0.3$ \\
\hline Fiber & $\%$ & $0.2 \pm 0.0$ & $0.2 \pm 0.0$ \\
\hline Calories & Kcal & $378.6 \pm 1.4$ & $361.6 \pm 1.2$ \\
\hline Hydrostability & $\%$ & $58.0 \pm 1.0$ & $57.8 \pm 6.7$ \\
\hline
\end{tabular}

The values are the means \pm standard deviations of three technical replicates.

The caloric content was determined with the following formula:

$\mathrm{cal}=(4 \mathrm{kCal} \times 1$ gcarbohydrate $)+(4 \mathrm{kCal} \times 1$ gprotein $)+(9 \mathrm{kCal} \times 1$ glipids $)$

and rice grains have been described as a source of carbohydrates that provide lowcost energy and improve pellet stability in water (Alhadi et al., 2013) and the inclusion of legumes such as chickpea provide a higher bioavailable and digestible protein content (Reyes-Moreno et al., 2000).

The commercial feed for shrimp farming has a higher protein content of animal origin (40\%) than the experimental feed with 3\% Spirulina maxima (17.5\%). However, some authors have indicated that crude protein levels can be reduced without adverse effects on the performance variables of shrimp culture (Brito et al., 2018; Lee and Lee., 2018). In this regard, Lee and Lee (2018), observed that the performance of shrimp in the pre-fattening stage $(0.65 \mathrm{~g})$ did not vary when using diets with a crude protein content of 25 to 50\%. Velasco et al. (2000), reported that diets with a protein content of $18 \%$ provide a growth benefit in shrimp ( $L$. vannamei) like the highest protein levels (25\%) in the first stage of culture. Furthermore, Lim and Persyn (1989), suggest that the protein value of diets of animal origin corresponds to crude protein that is not completely bioavailable. Mente et al. (2002), describe that the total use of the protein depends on the constitution of the amino acids, the quality and digestibility. Therefore, the ingredients of the experimental diet with the inclusion of Spirulina (3\%), had influential nutritional factors in the variables evaluated in the growth of shrimp in juvenile stage.

In this study, it was observed that the addition of Spirulina maxima improves the nutritional composition in comparison with the feed (chickpea and wheat) that does not contain it (Table 1). Recently, attention has been paid to the inclusion of chemical and natural attractors in diets to stimulate the intake and growth of farm animals (Ahamad et al., 2007). Jaime-Ceballos et al. (2017), pointed out the attraction power of the inclusion of Spirulina platensis to a commercial feed (animal protein) for shrimp farming. Therefore, it is possible that the inclusion of Spirulina maxima in the vegetable diet in this study may have presented a stimulating effect for the use of feed by shrimp. 
Table 2. Data of yield and survival of white shrimp (Litopenaeus vannamei) fed the experimental feed based on wheat (Triticum sativum) and chickpea (Cicer arietinum) enriched with 3\% spirulina (Spirulina maxima) and the control feed.

\begin{tabular}{|l|c|c|c|c|}
\multirow{2}{*}{ Variable } & \multicolumn{2}{|c|}{ Feed } & \multirow{2}{*}{ SEM } & P-value \\
\cline { 2 - 4 } & Experimental & Control & & \\
\hline IS (No.) & 80 & 80 & - & - \\
\hline FW (g) & $10.07^{\mathrm{b}}$ & $10.17^{\mathrm{a}}$ & 0.044 & 0.003 \\
\hline AW (g) & $0.75^{\mathrm{b}}$ & $0.76^{\mathrm{a}}$ & 0.216 & 0.006 \\
\hline SG (gdia-1) & $0.21^{\mathrm{a}}$ & $0.22^{\mathrm{a}}$ & 0.004 & 0.080 \\
\hline SV (\%) & $98.75^{\mathrm{a}}$ & $90.0^{\mathrm{b}}$ & 5.900 & 0.021 \\
\hline BP (g) & $0.74^{\mathrm{a}}$ & $0.68^{\mathrm{b}}$ & 0.042 & 0.037 \\
\hline
\end{tabular}

The values are the average of the experimental shrimp groups and are presented as mean \pm standard error of mean (SEM). Different letters represent significant difference $(P<0.05)$. Initial number of shrimps (IS); final weight (FW); average weight gain (AW); specific growth (SC); survival (SV); biomass production (BP).

\section{Growth and survival assessment}

Table 2 shows the growth and survival of shrimp cultured with the experimental and control diets.

The statistical analysis showed significant differences in final weight, average weight gain, biomass production and survival rate of the juvenile shrimp cultivated with the two types of feeds evaluated $(P<0.05)$ (Table 2$)$. It was determined that the shrimp fed with experimental diet presented a biomass production $(0.74 \pm 0.17 \mathrm{~g})$ and survival rate $(>98.75 \%)$ better than shrimp fed with commercial diet $(P<0.05)$. With both diets, an increase in the final weight of the shrimp was observed over time $(\mathrm{r}=0.88, P<0.05)$ (Figure 1 ) and a similar daily growth rate of $0.22 \pm 0.05 \mathrm{~g} \mathrm{day}^{-1}(P>0.05)$ (Table 2$)$.

Suárez et al. (2009), have previously proposed the use of plant-based feeds as an alternative for shrimp farming since they favor feed conversion and the quality of the culture water. Olmos et al. (2011), report having obtained a daily growth rate of biomass with the supply of a formulation of soy and Bacillus subtilis of $0.169 \mathrm{~g}$ day $^{-1}$ and with a commercial food based on fish meal of $0.154 \mathrm{~g}^{\mathrm{d}} \mathrm{day}^{-1}$, during 20 days of shrimp culture in glass tanks. In the present study (Figure 1 and Table 2), it was possible to obtain a daily increase in biomass of $0.23 \mathrm{~g}^{\mathrm{day}} \mathrm{day}^{-1}$ in shrimp fed a diet of plant origin containing Spirulina, which is higher than previously reported. Likewise, the growth variables observed in this study agree with those previously reported for diets with protein content of 18\% (Velasco et al., 2000) and 25\% (Lee and Lee, 2018). Therefore, this study presents evidence of the feasibility of using a wheat and chickpea-based diet enriched with Spirulina maxima (3\%), for feeding shrimp and potentially other crustaceans under farm conditions.

Currently, there is a trend to include immunostimulants into diets for disease prevention and reduction of early shrimp mortality (Wang et al., 2016). GutierrézSalmeán et al. (2015), published a review of the use of algae, in particular Spirulina, as a functional feed in diets for different experimental animals. They concluded that the inclusion of Spirulina up to a concentration of 5\% in the diet did not cause any symptoms of toxicity. Additionally, Nuhu (2013), reported that the addition of Spirulina maxima to the diet constitutes an ingredient that strengthens the immune 


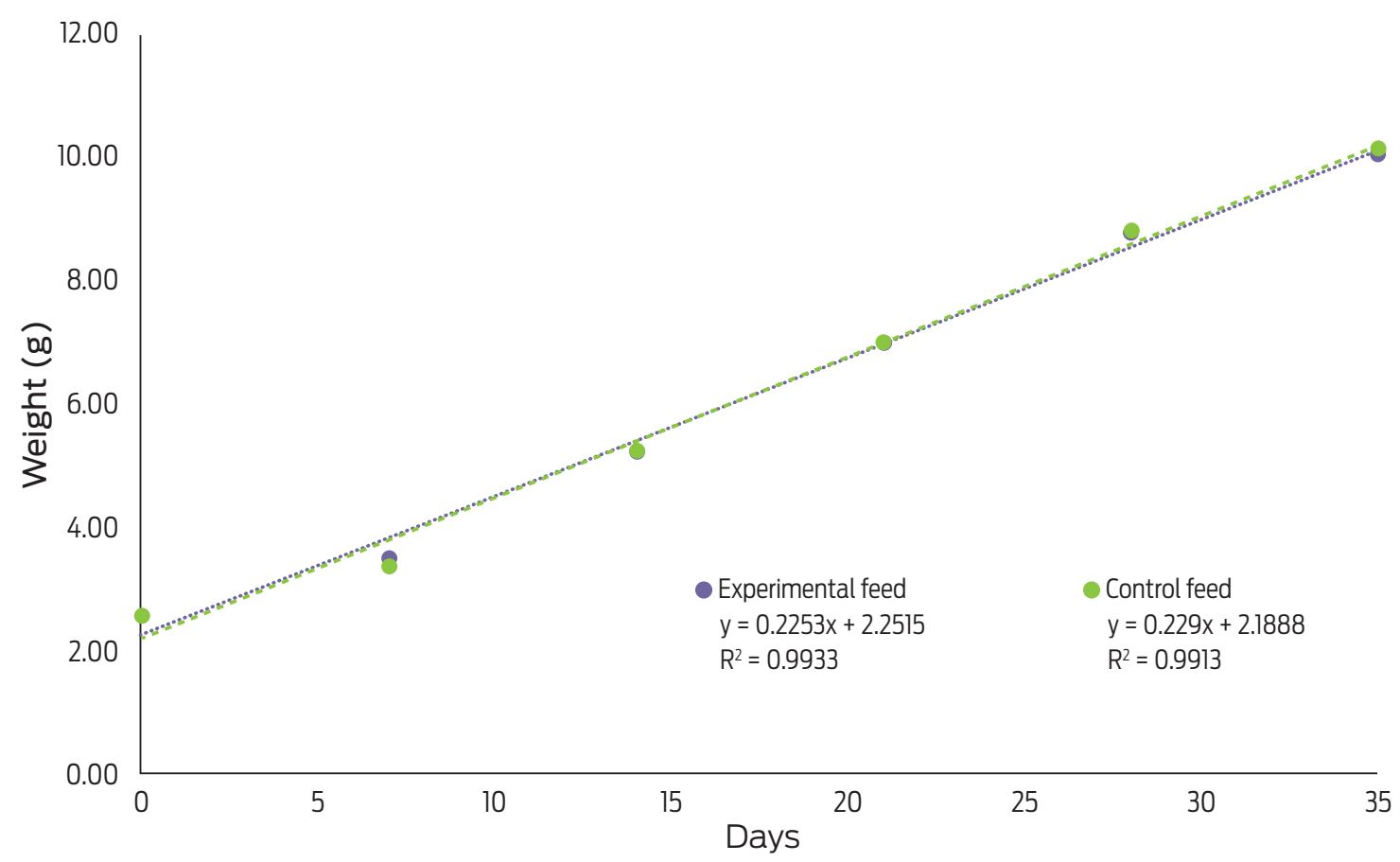

Figure 1. Daily growth rate of white shrimp (Litopenaeus vannamei) fed with the experimental feed based on wheat (Triticum sativum) and chickpea (Cicer arietinum) enriched with 3\% spirulina (Spirulina maxima). The growth kinetics of the experimental group of shrimps for both foods was adjusted to a zero-order model $\left(R^{2}=0.995\right)$, and the rate $(\mu)$ of total biomass (g.day $\left.{ }^{-1}\right)$ during raising was not statistically significant $(P>0.05)$.

system due to its nutritional, antioxidant, and antimicrobial properties. These reports are in accordance with the data in Tables 2 and 3 that indicate the superior survival and the best state of health of the shrimp fed with the vegetable feed, containing Spirulina maxima. Furthermore, Chen et al. (2016), have shown the effect of the immunostimulant and preventive power of $V$. alginolyticus infection in shrimp fed with diets supplemented with Spirulina.

\section{Health analysis}

The health analysis of the shrimp fed with both feeds is shown in Table 3. In the fresh analysis of the hemolymph and the hepatopancreas, no filamentous bacteria were observed in the shrimp fed with the experimental and control feeds. The health variables of the gills and the hepatopancreas of both experimental groups were mostly at a low severity level. However, in the intestine, the low presence of gametocytes is shown in most of the shrimp fed with the experimental feed (60\%) and the control feed (40\%).

The health analysis shows that most of the analyzed shrimp present an acceptable health (Table 3). However, some specimens analyzed indicate damage to the hepatopancreas, gills and intestine. The development of these pathological damages has been related to stress and shrimp culture conditions (Borges et al., 2012). The damage and lipid content in the hepatopancreas are related to its ability to metabolize nutrients, leading to altering the development of the crustacean (Gómez-Gil et al., 2001). In this sense, it is observed that the shrimp of both 
Table 3. Microbiological and pathological data of white shrimp (Litopenaeus vannamei) fed with the experimental feed based on wheat (Triticum sativum) and chickpea (Cicer arietinum) enriched with 3\% spirulina (Spirulina maxima) and the control feed.

\begin{tabular}{|c|c|c|c|}
\hline Organ & Damage & $\begin{array}{l}\text { Experimental feed } 3 \% \\
\text { Spirulina }(n=5)\end{array}$ & $\begin{array}{l}\text { Control feed } \\
(n=5)\end{array}$ \\
\hline Hemolymph & Bacteria & $-(100 \%)$ & $-(100 \%)$ \\
\hline \multirow[t]{4}{*}{ Hepatopancreas } & Bacteria & $-(100 \%)$ & $-(80 \%) ;+(20 \%)$ \\
\hline & Melanization & $-(100 \%)$ & $-(100 \%)$ \\
\hline & Tubular deformation & $-(100 \%)$ & $-(80 \%) ;++(20 \%)$ \\
\hline & Lipid shortage & $-(100 \%)$ & $-(80 \%) ;++(20 \%)$ \\
\hline \multirow[t]{2}{*}{ Gills } & Organic matter & $-(80 \%) ;+(20 \%)$ & $-(100 \%)$ \\
\hline & Zothanium & $-(60 \%) ;+(20 \%)++(20 \%)$ & $-(80 \%) ;+(20 \%)$ \\
\hline Intestine & Gametocytes & $-(40 \%) ;+(60 \%)$ & $-(60 \%) ;+(40 \%)$ \\
\hline
\end{tabular}

experimental groups have a favorable response for the absorption of the feeds (Table 3). The presence of gametocytes is relevant given that their accumulation in the intestine of shrimp can favor the development of parasitic diseases (Fajer-Avila et al., 2005). In this sense, it can be hypothesized that the bioactive properties of Spirulina (Nuhu, 2013; Gutiérrez-Salméan et al., 2015; Chen et al., 2016) contained in the experimental feed reinforce the immune system of the crustacean during the stage of pre-fattening by favoring their survival in this study (Table 2).

\section{Salinity monitoring in farm water}

The salinity values of the farms are shown in Figure 2. Salinity is not related to survival $(r=-0.156, P>0.05)$ and daily weight $(r=-0.004, P>0.05)$ of the shrimp cultured with both feeds.

A physicochemical parameter that can condition shrimp growth and survival is the saline concentration of the culture water ${ }^{8}$. In addition, Valenzuela-Quiñonez et al. (2010), indicates that shrimp specific growth can be observed with low salinity concentrations ( $1 \mathrm{mg} \cdot \mathrm{L}^{-1}$ ) and increased with values up to $35 \mathrm{mg} \cdot \mathrm{L}^{-1}$. Recognizing the indicated importance of salinity in the culture medium, the salinity values quantified in this study were within the marked limits for the water used in shrimp culture, according to the domestic criteria (27-35.0 mg. $\mathrm{L}^{-1}$ ) of CE-CCA-001/89 (DOF, 1989). The results of growth variables obtained with both feeding strategies (Figure 2), indicate that the salt concentration maintained the stability of these important quality variables. Moreover, these results indicate that the experimental feed used can be implemented in farms whose culture conditions are similar. 


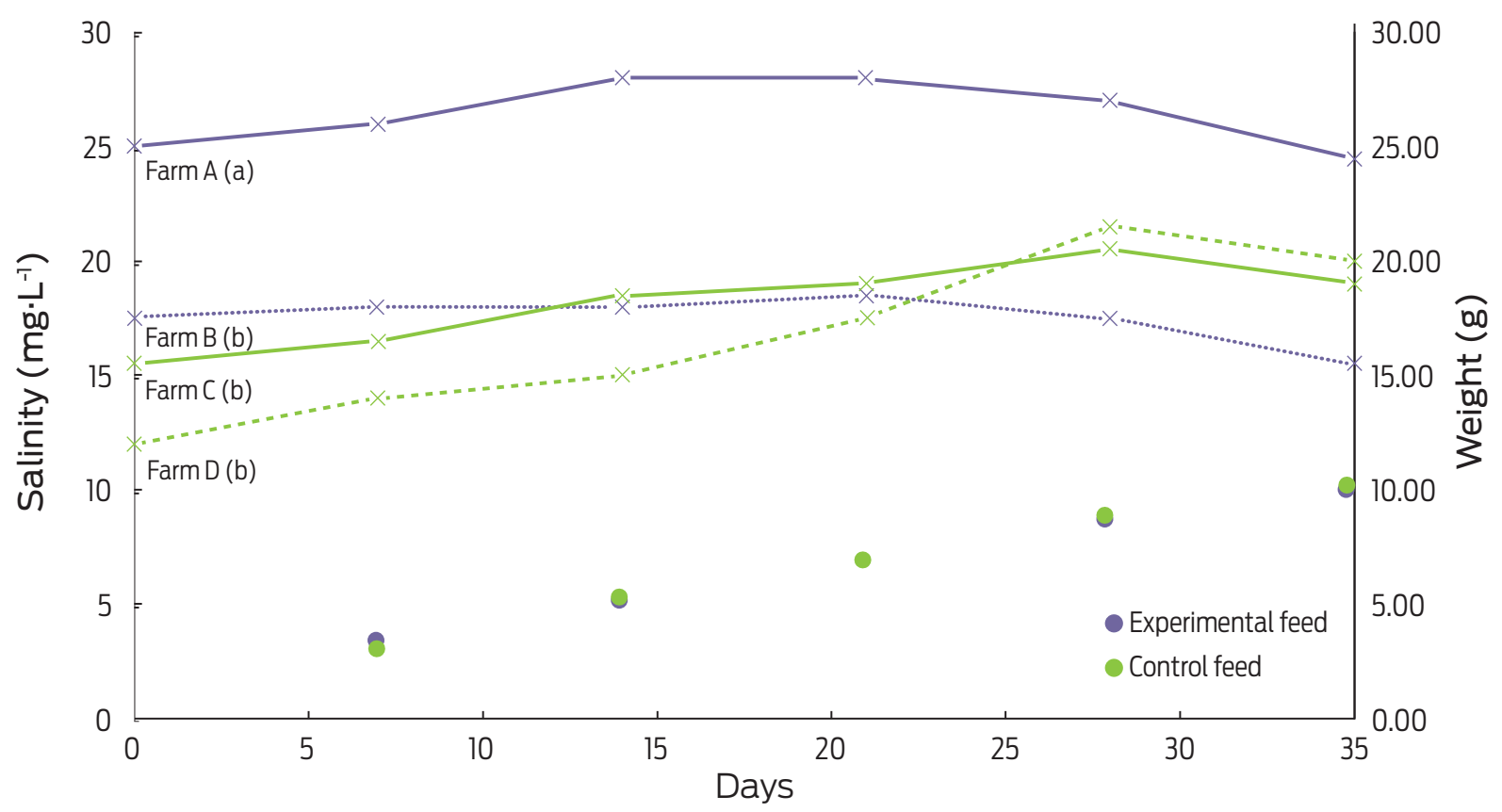

Figure 2. Saline concentration of water of shrimp's farms. The total daily weight of shrimp fed with the experimental feed with 3\% Spirulina and commercial feed is represented by the black and gray spots, respectively. Values with different lowercase letters into parentheses are statistically different between farms $(P<0.05)$.

\section{Conclusions}

The results of the present study indicate that the feed made from wheat (Triticum sativum) and chickpea (Cicer arietinum) containing 3\% Spirulina maxima offers an effective feeding option for the white shrimp production (Litopenaeus vannamei) in pre-fattening stage, it acts as a source of nutrition and energy, which increases their performance and improves their health. Additionally, the experimental feed based on vegetable protein has a hydrostability that favors the use of the feed by the shrimp. The trend of incorporating immunostimulants such as Spirulina maxima into diets could help reduce shrimp mortality. Based on the experience of this study, the formulation of balanced feeds is suggested, with mixtures of different vegetable proteins enriched with immunostimulants to optimize the yield and nutrition of farm-grown shrimp. 


\section{Acknowledgments}

The present study was financially supported by the Program for Support to Scientific and Technological Research-2017 of National Technologic Institute of Mexico (grant 6069.17-P). The authors thank the technical support of Ms. Alexandra Traslaviña López and Ms. Jazmín Candelaria Pérez Ceballos, as well as Mr. José Luis Cepeda Canizales for facilitating the experiment on the farms.

\section{Conflicts of interest}

The authors declare no conflict of interest related to this manuscript.

\section{Author contributions}

IAML: Conceptualization, funding acquisition, methodology and manuscript revision. GMCR: Formal analysis and writing-original draft.

JJB: Writing-original draft.

AJFL: Methodology and project-administration.

\section{References}

Ahamad, A.S., Gopal, C., and Ramana, J.V. (2007). Attractant and growth promoting properties of some feed materials and chemicals incorporated in the diets for Penaeus monodon (Fabricius). Indian Journal of Fisheries, 54(1), p. 67-73.

Alhadi, I.K., Ahmad, A.B., and Abol-Munafi, A.B. (2013). Water stability and nutrient leaching of different levels of maltose formulated fish pellets. Global Veterinaria, 10(6), p. 638-642.

Amaya, E.A., Allen, D., and Rouse, D. (2007). Replacement of fish meal in practical diets for the Pacific white shrimp (Litopenaeus vannamei) reared under pond conditions. Aquaculture, 262(2), p. 393-401. doi: 10.1016/j. aquaculture.2006.11.015.

AOAC. Official methods of analysis. (1990). 15th ed. Washington, DC: Association of Official Analytical Chemists.

Ayisi, C.L., Hua, X., Apraku, A., Afriyie, G., and Kyei, B.A. (2017). Recent studies toward the development of practical diets for shrimp and their nutritional requirements. HAYATI Journal of Biosciences, 24(3), p. 109-117. doi: 10.1016/j. hjb.2017.09.004.

Borges, M.R.O., Mendoza, Y.J., and Carbonell, N.M. (2012). Necrosis en postlarvas de camarón. Revista Electrónica de Veterinaria, 13(2), p. 1-4.

Brito, L.O., Junior, L.C., Abreu, J.L., Severi, W., Moraes, L.B.S., and Galvez, A.O. (2018). Effects of two commercial feeds with high and low crude protein content on the performance of white shrimp Litopenaeus vannamei raised in an integrated biofloc system with the seaweed Gracilaria birdiae. Spanish Journal of Agricultural Research, 16(1), p. 1-7. doi: 10.5424/sjar/2018161-11451.

Chen, Y.Y., Chen, J., Tayag, C.M., Li, H., Putra, D.F., Kuo, Y.H., Bai, J.C., and Chang, Y.H. (2016). Spirulina elicits the activation of innate immunity and increases resistance against Vibrio alginolyticus in shrimp. Fish \& Shellfish Immunology, 55, p. 690-698. doi: 10.1016/j.fsi.2016.06.042.

Cock, J., Gitterle, T., Salazarm, M., and Rye, M. (2009). Breeding for disease resistance of Penaeid shirmps. Aquaculture, 286(1-2), p. 1-11.doi: 10.1016/j. aquaculture.2008.09.011. 
CONAPESCA. Consejo Nacional de Acuacultura y Pesca. (2018). Anuario estadístico de acuacultura y pesca. Available at: https://www.conapesca.gob.mx/work/ sites/cona/dgppe/2018/ANUARIO_2018.pdf

Cortés, A., Casillas-Hernández, R., Cambeses-Franco, C., Bórquez-López, R., Magallón-Barajas, F., Quadros-Seiffert, W., Feijoo, G., and Moreira, M. (2021). Eco-efficiency assessment of shrimp aquaculture production in Mexico. Aquaculture, 544(15), p. 1-10. doi: 10.1016/j.aquaculture.2021.737145.

DOF. Diario Oficial de la Federación. (1989). CE-CCA-001/89 Acuerdo por el que se establecen los criterios ecológicos de calidad del agua. Available at: http:// legismex.mty.itesm.mx/acu/acca001.pdf

Espinoza-Chaurand, L.D., Silva-Loera, A., García-Esquivel, Z., and López-Acuña, L.M. (2015). Uso de harina de cabeza de camarón como reemplazo proteico de harina de pescado en dietas balanceadas para juveniles de Totoaba macdonaldi (Gilbert, 1890). Latin America Journal of Aquatic Research, 43(3), p. 457-465. doi: 10.3856/vol43-issue3-fulltext-7.

Fajer-Ávila, E.J., Morales, M.S., Abad-Rosales, S., Roque, A., Meza-Bojórquez, P., and Hernández-González, C. (2005). Effectiveness of oral Elancobank and Avimix-STk against Nematopsis (Apicomplexa: Porosporidae) gametocyts infecting the shrimp Litopenaeus vannamei. Aquaculture, 244(1-4), p. 11-18. doi: 10.1016/j.aquaculture.2004.11.005.

Gómez-Gil, B., Roque, A., and Guerra, F. (2001). Enfermedades infecciosas más comunes en la camaronicultura en México y el impacto del uso de antimicrobianos. In: Camaronicultura y medio ambiente. Mexico: Instituto de Ciencias del Mar y Limnología-UnAM.

Gutiérrez-Salmeán, G., Fabila-Castillo, L., and Chamorro-Cevallos, G. (2015). Nutritional and toxicological aspects of Spirulina (Arthrospira). Nutrición Hospitalaria, 32(1), p. 34-40. doi: 10.3305/nh.2015.32.1.9001.

Jaime-Ceballos, B., Civera, R., Villarreal, C.H., Galindo, J., and Pérez-Jar, L. (2017). Uso de la harina de Spirulina platensis como atrayente en el alimento para el camarón Litopenaeus schmitti. Hidrobiológica, 17(2), p. 113-117.

Joblingh, M. (2012). National Research Council (NCR): Nutrient requirements of fish and shrimp. Aquaculture International, 20, p. 601-602. doi: 10.1007/ s10499-011-9480-6.

Lee, C., and Lee, K.J. (2018). Dietary protein requirement of Pacific white shrimp Litopenaeus vannamei in three different growth stages. Fisheries \& Aquatic Sciences, 21 (30), p. 1-6. doi: 10.1186/S41240-018-0105-0.

Lim, C., and Persyn, A. (1989). Practical feeding-penaeid shrimps. Boston, Massachusetts: Nutrition and Feeding of Fish, Springer.

Macias-Sancho, J., Poersch, L.E., Bauer, W., Romano, L.A., Wasielesky, W., and Borges, M. (2014). Fishmeal substitution with Arthrospira (Spirulina platensis) in a practical diet for Litopenaeus vannamei: Effects on growth and immunological parameters. Aquaculture, 426-427, p. 120-125. doi: 10.1016/j. aquaculture.2014.01.028.

Mente, E., Coutteau, P., Houlihan, D., Davidson, I., and Sorgeloos, P. (2002). Protein turnover, amino acid profile and amino acid flux in juvenile shrimp Litopenaeus vannamei: effects of dietary protein source. Journal of Experimental Biology, 205(20), p. 3107-3122. doi: 10.1242/jeb.205.20.3107. 
Nuhu, A. (2013). Spirulina (Arthrospira): an important source of nutritional and medicinal compounds. Journal of Marine Sciences, 2013, p. 1-8. doi: $10.1155 / 2013 / 325636$.

Obaldo, L.G., Divakaran, S., and Tacón, A.G. (2002). Methods for determining the physical stability of shrimp feeds in water. Aquaculture Research, 33(5), p. 369377. doi: 10.1046/j.1365-2109.2002.00681.x.

Olmos, J., Ochoa, L., Paniagua-Michel, J., and Contreras, R. (2011). Functional feed assessment on Litopenaeus vannamei using 100\% fish meal replacement by soybean meal, high levels of complex carbohydrates and Bacillus probiotic strains. Mar Drugs, 9(6), p. 1119-1132. doi: 10.3390/md9061119.

Rahman, R.A., Graham, K., Ramli, R., Jamari, Z., and Ku-Mhamud, K.R. (2017). Shrimp feed formulation via evolutionary algorithm with power heuristics and handling constraints. Complexity, 2017(11), p. 1-12. doi: 10.1155/2017/7053710.

Reyes-Moreno, C., Romero-Urías, C.A., Milán-Carrillo, J., and Gómez-Garza, R.M. (2000). Composición química y calidad nutritiva del garbanzo (Cicer arietinum L.) fresco y endurecido después de la fermentación en estado sólido (FES). Food Science and Technology International, 6(3), p. 251-258. doi: 10.1177/1 08201320000600308.

Simão, B.R., Brito, L.O., Campos, A.S., Cabral, L., and da Silveira, C.M. (2013). Stocking densities and feeding strategies in shrimp and tilapia polyculture in tanks. Pesquisa Agropecuaria Brasileira, 48(8), p. 1088-1095. doi: 10.1590/ S0100-204X2013000800039.

Stevanato, F.B., Almeida, V.V., Matsushita, M., Oliveira, C.C., Souza, N.E., and Viseintainer, J.V. (2008). Fatty acids and nutrients in the flour made from tilapia (Oreochromis niloticus) heads. Ciencia e Tecnologia de Alimentos, 28(2), p. 2440-2443. doi: 10.1590/S0101-20612008000200027.

Suárez, J.A., Gaxiola, G., Mendoza, R., Cadavid, S., García, G., Alanis, G., Suárez, A., Faillace, J., and Cuzon, G. (2009). Substitution of fish meal with plant protein sources and energy budget for white shrimp Litopenaeus vannamei (Boone, 1931). Aquaculture, 289(1-2), p. 118-123. doi: 10.1016/j.aquaculture. 2009.01.001.

Tang, G., and Suter, P.M. (201 1). Vitamin A, nutrition, and health values of algae: Spirulina, Chlorella, and Dunaliella. Journal of Pharmacy and Nutrition Sciences, 1(2), p. 111-118. doi: 10.6000/1927-5951.2011.01.02.04.

Valenzuela-Quiñonez, W., Rodríguez-Quiroz, G., and Esparza-Leal, HM. (2010). Cultivo intensivo de camarón blanco Litopenaeus vannamei (boone) en agua de pozo de baja salinidad como alternativa acuícola para zonas de alta marginación. Ra Ximhai, 6(001), p. 1-8.

Velasco, M., Lawrence, A.L., Castille, F.L., and Obaldo, L.G. (2000). Dietary protein requirement for Litopenaeus vannamei. En: Cruz -Suárez, L.E., Ricque-Marie, D., Tapia-Salazar, M., Olvera-Novoa, M.A., and Civera-Cerecedo, R. (editores). Avances en Nutrición Acuícola. Memorias del Quinto Simposium Internacional de Nutrición Acuícola. 19-22 noviembre. Mérida, Yucatán, México.

Vinatea, L., Muedas, W., and Arantes, R. (2011). The impact of oxygen consumption by the shrimp Litopenaeus vannamei according to body weight, temperature, salinity, and stocking density on pond aeration: a simulation. Acta Scientiarum Biological Science, 33(2), p. 125-132. doi: 10.4025/actascibiolsci.v33i2.7018. 
Wang, W., Sun, J., Liu, C., and Xue, Z. (2016). Application of immunostimulants in aquaculture: current knowledge and future perspectives. Aquaculture Research, 48(1), p. 1-23. doi: https://doi.org/10.1111/are.13161

Žilić, S., Barać, M., Pešić, M., Dodig, D., and Ignjatović-Micić, D. (201 1). Characterization of proteins from grain of different bread and durum wheat genotype. International Journal of Molecular Sciences, 12(9), p. 5878-5894. doi: 10.3390/ ijms 12095878. 